\title{
Physico-Chemical Properties of Kaolin-Organic Acid
}

\author{
S.W. Yeo ${ }^{1}$, Felix N. L. Ling ${ }^{1,}$, V. S. Low ${ }^{2}$, and K. L. Toh ${ }^{2}$ \\ ${ }^{1}$ Research Center for Soft Soil (RECESS), Universiti Tun Hussein Onn Malaysia, 86400 Parit Raja, \\ Batu Pahat, Johor, Malaysia \\ ${ }^{2}$ Faculty of Civil \& Environmental Engineering., Universiti Tun Hussein Onn Malaysia, 86400 Parit \\ Raja, Batu Pahat, Johor, Malaysia
}

\begin{abstract}
Soil with more than $20 \%$ of organic content is classified as organic soil in Malaysia. Contents of organic soil consist of different types of organic and inorganic matter. Each type of organic matter has its own characteristic and its effect on the properties of the soil is different. Hence, a good understanding on the effect of specific organic and inorganic matter on the physico-chemical characteristic of organic soils can serve as a guide for predicting the properties of organic soils. The main objective is to unveil the effect of organic acid on the physico-chemical properties of soil. Artificial organic soil (kaolin mixed with organic acid) was utilized in order to minimize the geochemical variability of studied soil. The organic acid which consists of humic acid and fulvic acid was extracted from highly humificated plant-based compost. The effect of organic acid on the physico-chemical properties of soil was determined by varying the concentration of organic acid. The specific gravity, Atterberg limits, $\mathrm{pH}$, bulk chemical composition and the functional group of kaolin-organic acid were determined. It was found that the plasticity index, specific gravity and $\mathrm{pH}$ value were decreased with lowered concentration of organic acid. However, the liquid limits and plastic limits were found to be increased with the concentration decrement of organic acid. The analysis of XRF on the bulk chemical composition and analysis of FTIR spectra on the functional group of artificial organic soils with different concentration have confirmed little geochemical variability between samples.
\end{abstract}

\section{Introduction}

Malaysia, which situated at the tropical belt is rich in peat soil. Maintenance of road construction over peat soil deposit faced great challenges and cost millions of funding on it. Besides that, the most commonly used soil replacement method and resting structures on piles over peat deposits were also reported to be not social-economic sustainable [1].

Peat is generally consists of fragmented organic materials that formed in wetlands which is termed as soil organic matter. The contents of peat varies with location due to the factors such as degree of humification, temperature and origin of fiber [2]. However, it was

*Corresponding author: felix@uthm.edu.my 
reported that the peat properties of Hokkaido peat that had been studied has many similarities when compared with Malaysia peat particularly with Johor peat. Both peat soils were reported to be hemic peat with high ash contents and lightly acidic [3]. Hence, it motivated more studies to generalize the behavior of peat and organic soil through artificial soil $[4,5,6]$.

Basically, soil organic matter is derived from the soil biomass, which consists of both living and dead organic matter [7]. Thus, soil organic matter can be classified into two major categories which are living organic matter and non-living organic matter. In general, soil biota such as bacteria, fungi and algae, and others fresh undecomposed animal or plant debris were categorized as living organic matter (a minor fraction of soil organic matter). The major faction of soil organic matter, which is non-living organic matter, can be defined as the plant or animals at different stages of decomposition and transformation.

Non-living organic matter can be further divided into humified and non-humified organic matter depending on its degree of humification. Humic substances which consist of fulvic acid, humic acid and humin are categorized as humified organic matter [4]. Studies found that highly humified matter can coagulate the soil particles resulting in bigger particles which may reduce the compatibility of soil [8] increases the elasticity and deformation resistance of the aggregates and thus increases the stability and strength of aggregates [9]. However, it was reported that the settlement of embankments over peat deposit with high organic content remains excessively large and continued for many years $[10,11]$. The findings of the previous researcher $[8,9,10]$ showed that the effect of organic matter was different with the contents of organic matter. Hence, it emerged a need to enhance the understanding of effect of various organic matters on the physico-chemical properties of soil.

\section{Materials and methods}

Artificial organic soils were used in this study for the purpose to minimize the geochemical variability that normally encountered in natural organic soils. Commercial processed kaolin grade S300 was used as base soil. Kaolin grade S300 which marketed by Kaolin (M) Sdn. Bhd. was reported to be dominant silt sized with small contents of sand and clay sized particles [12]. Organic acid utilized in this study was extracted from highly humificated plant-based compost. The organic acid was determined to consist of $0.37 \%$ humic acid and $46.60 \%$ fulvic acid [13]. A total $15 \%$ of organic acid based on dry weight of kaolin were mixed with kaolin to form artificial organic soils. Organic acid was prepared in four different dilution factors with distilled water in order to study the effect of organic acid on the properties of soil. The dilution factor of organic acid was named based on its ratio to the distilled water which was 1:0, 1:1, 1:2 and 1:3 respectively. Table 1 summarizes the percentage of each composition of artificial organic soil samples that utilized in this study.

Table 1. Composition of artificial organic soils.

\begin{tabular}{|l|c|c|c|c|}
\hline \multirow{2}{*}{ Material } & \multicolumn{4}{|c|}{ Percentage for each component (\%) } \\
\cline { 2 - 5 } & Soil 1 & Soil 2 & Soil 3 & Soil 4 \\
\hline Kaolin S300 & 85 & 85 & 85 & 85 \\
\hline Organicacid & 15 & 7.5 & 5 & 3.7 \\
\hline Distilled water & 0 & 7.5 & 10 & 11.3 \\
\hline
\end{tabular}

Physical properties of the artificial organic soils namely Atterberg limits (liquid limit, and plastic limit), and specific gravity were determined. The liquid limit of the soil samples were determined by using cone penetrometer method based on standard specification [14]. Whereas, the plastic limit of soil samples were determined by using modified cone 
penetrometer method [15]. The procedure is same as the liquid limit and the only differences was the mass of the cone. Modified cone penetromenter method utilizing a cone with $240 \mathrm{~g}$ weight, 3 times heavier than standard liquid limit cone with same geometry and penetration depth for plastic limit test. Small pycnometer method was used to determine the specific gravity of soils based on standard specification [14].

The $\mathrm{pH}$ of the artificial organic soils was determined by using electrometric method with reference to standard specification [16]. A total amount of $30 \mathrm{~g}$ dry soil was mixed with $75 \mathrm{~mL}$ of distilled water in a $100 \mathrm{~mL}$ beaker for $\mathrm{pH}$ determination. The X-ray fluorescence (XRF) and Fourier Transform Infrared Spectroscopy (FTIR) were utilized to determine the geochemical composition of artificial organic soil samples with various dilution factors by determining its bulk chemical composition and functional group.

\section{Results and discussion}

Table 2 shows the physico-chemical properties test that had been carried out for kaolinorganic acid in different concentration. Based on the data collected, the differences between use of pure organic acid and after diluted can be seen. Soil samples with less concentration organic acid shows higher value in liquid limit and plastic limit compared to the soils with more concentrated organic acid. Fig. 1 shows the plasticity range were determined for the kaolin-organic acid with different concentration. The differences between the two boundaries were defined as plasticity index where the upper and lower boundary is element for liquid limit and plastic limit. Hence, with the plasticity index value, soils samples are classified as intermediate plasticity silt based on plasticity chart. The specific gravity of soil samples decreasing when the concentration of organic acid used are less concentrated. The average specific gravity of kaolin S300 was determined as 2.6 [17]. As for this study, the used of kaolin as the clay material to mixed with organic acid have produced the specific gravity between the ranges of 2.6 to 2.7 that can be accepted as well. From previous researcher [18], the plastic limit and liquid limit for kaolin-humic acid both shows decreasing when humic acid content increases. In contrast, the Atterberg limit for kaolinorganic acid were shown increasing when the dilution factor increasing. In the same paper reported that the specific gravity for kaolin-humic acid decreased when the humic acid content increasing. Simultaneously, when the used of organic acid is less concentrated, the specific gravity of soil samples were slightly decreasing.

Table 2. Physico-chemical properties for kaolin - organic acid in different concentration.

\begin{tabular}{|l|c|c|c|c|}
\hline \multirow{2}{*}{$\begin{array}{l}\text { Physico- } \\
\text { chemicalPropertiesTesting }\end{array}$} & \multicolumn{4}{|c|}{ Percentage for each component (\%) } \\
\cline { 2 - 5 } & Soil 1 & Soil 2 & Soil 3 & Soil 4 \\
\hline Liquidlimit (\%) & 36.8 & 37.2 & 37.5 & 38.0 \\
\hline Plastic limit (\%) & 33.1 & 33.6 & 35.0 & 35.7 \\
\hline Plasticity index (\%) & 3.7 & 3.6 & 2.5 & 2.3 \\
\hline Specificgravity & 2.80 & 2.66 & 2.66 & 2.64 \\
\hline pH & 6.68 & 6.66 & 6.35 & 6.18 \\
\hline
\end{tabular}

For chemical properties test, through the $\mathrm{pH}$ testing can know that, the $\mathrm{pH}$ value for kaolin was 4.74 and the organic acid had $\mathrm{pH}$ value of 7.74. Overall, all the soil samples had the $\mathrm{pH}$ value in the range of 6.18 to 6.68 which is in between the pure kaolin and organic acid. The $\mathrm{pH}$ value of soil samples shows more acidic when distilled water is added for dilution purpose. XRF test are carried out and the results are summarized as below Table 3. Theoretically, magnesium oxide $(\mathrm{MgO})$ and potassium oxide $(\mathrm{K} 2 \mathrm{O})$ content will increase the soil $\mathrm{pH}$. However, the $\mathrm{pH}$ result in this study did not comply with this condition. This may due to the characteristic of organic acid that are mostly soluble either in acid and base 
environment. Fig. 2 shows the FTIR spectra for kaolin-organic acid in different concentration. All the samples exhibits sharp bands in the region of wavelength 1100-1000 and 990-945, which can attributed to Si-O-C groups.

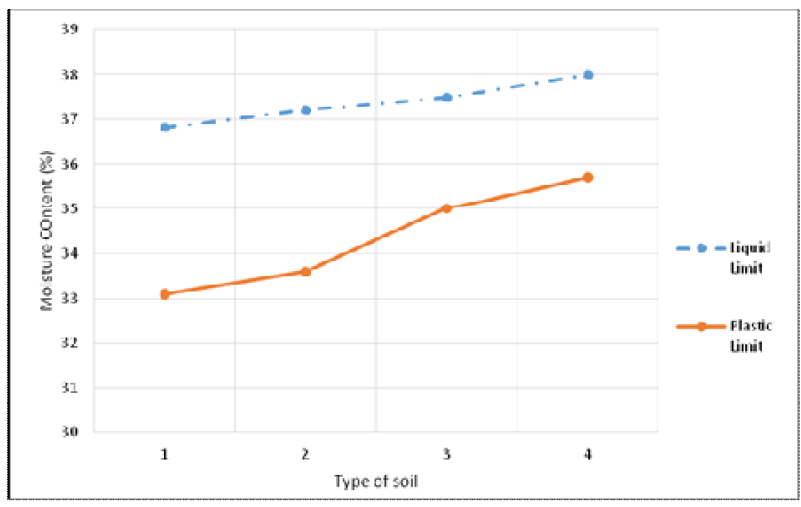

Fig. 1. Effect of concentration on plasticity of kaolin-organic acid.

Table 3. XRF result for kaolin - organic acid in different dilution factor

\begin{tabular}{|c|c|c|c|c|}
\hline \multirow{2}{*}{ Formula } & \multicolumn{4}{|c|}{ Sample } \\
\cline { 2 - 5 } & Soil 1 & Soil 2 & Soil 3 & Soil 4 \\
\hline $\mathrm{SiO}_{2}$ & $48.30 \%$ & $49.80 \%$ & $50.80 \%$ & $50.40 \%$ \\
\hline $\mathrm{Al}_{2} \mathrm{O}_{3}$ & $11.70 \%$ & $17.40 \%$ & $17.80 \%$ & $16.30 \%$ \\
\hline $\mathrm{K}_{2} \mathrm{O}^{*}$ & $3.10 \%$ & $3.62 \%$ & $3.57 \%$ & $3.56 \%$ \\
\hline $\mathrm{C}$ & $1.00 \%$ & $1.06 \%$ & $1.11 \%$ & $1.00 \%$ \\
\hline $\mathrm{Fe}_{2} \mathrm{O}_{3}$ & $0.76 \%$ & $1.00 \%$ & $1.00 \%$ & $0.97 \%$ \\
\hline $\mathrm{MgO}^{*}$ & $0.64 \%$ & $0.82 \%$ & $0.83 \%$ & $0.87 \%$ \\
\hline $\mathrm{TiO}_{2}$ & $0.60 \%$ & $0.74 \%$ & $0.77 \%$ & $0.66 \%$ \\
\hline $\mathrm{ZrO}_{2}$ & $0.35 \%$ & $0.56 \%$ & $0.59 \%$ & $0.46 \%$ \\
\hline Percentage** & 0.056 & 0.0592 & 0.058 & 0.060 \\
\hline
\end{tabular}

*Alkaline and alkali earthelements

**Percentage of alkaline \& alkali earth elements over total inorganic element

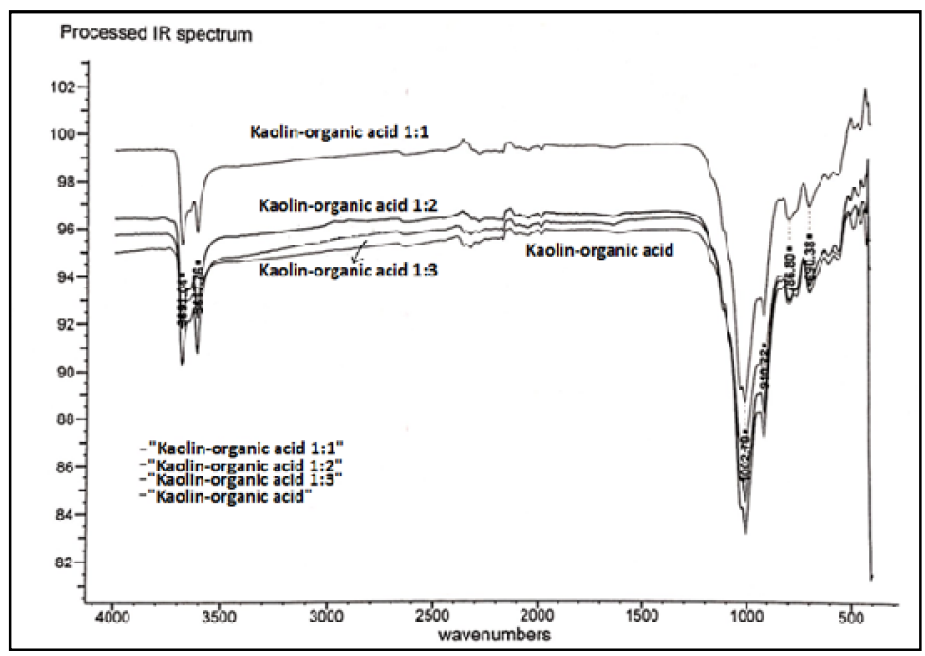

Fig. 2. FTIR Spectra of kaolin-organic acid in different concentration. 


\section{Conclusion}

Throughout this study, the effect of concentration on the physico-chemical characteristic had been identified. When the concentration of organic acid become less concentrated, the physical and chemical characteristic such as liquid limit and plastic limit shows increasing but the plasticity index decreased when dilution factor of organic acid increased. However, the $\mathrm{pH}$ value shows more acidic when the concentration for organic acid used are decreased. Furthermore, all the soil samples are mainly composed by silicon oxide based on the XRF and FTIR result. Overall, the results obtained throughout this study will be benefit for the understanding on basic characteristic of soil samples as a reference for further experiment to determine the strength and improvement in real construction environment.

The authors wish to express grateful and thankful appreciate to the financial support from University Tun Hussein Onn Malaysia through the Centre for Graduate Studies and Office for Research, Innovation, Commercialization and Consultancy Management (ORICC). The authors also thanks all laboratory technicians in Research Centre for Soft Soil (RECESS), Department of Infrastructure and Geomatic Engineering, Department of Water and Environmental Engineering of Faculty of Civil and Environmental Engineering, Universiti Tun Hussein Onn Malaysia. Their advice, knowledge and technical support had made this research possible.

\section{References}

[1] M.K. Abu Talib, Effectiveness of sugarcane bagasse ash (SCBA) utilization in peat stabilization, PhD Thesis, Kyushu University, Fukuoka, (2016)

[2] S. Kazemian, B.B.K. Huat, A. Prasad, M. Barghchi, A state of art review of peat: Geotechnical engineering perspective, Int. J. of the Phys. Sciences, 6(8), 1974-1981 (2011)

[3] M.K. Abu Taib, Y. Noriyuki, An overview on Japan and Malaysia peat relating to geotechnical characteristic, Int. J. of Integrated Eng., 6(1), 1-7 (2014)

[4] K. Kujala, M. Makikyro, O. Lehto, Effect of humus on the binding reaction in stabilized soils, Proc of the Int. Conf on Ground Improvement and Geosystems, Tokyo, 415-420 (1996)

[5] H. Tremblay, J. Duchesne, J. Locat, S. Leroueil, Influence of the nature of organic compounds on fine soil stabilization with cement, Can. Geotech. J., 39, 535-546 (2002)

[6] C. Modmoltin, J. Lu, K. Onitsuka, Influence of humic acid and salt concentration on lime-stabilized ariake clays and microstructure research, Chinese J. of Geotech. Eng. 26(2), 281-286 (2004)

[7] K.H. Tan, Humic Matter in Soil and the Environment. Principles and Controversies, Marcel Dekker Inc., New York, (2003)

[8] R. Sugita, Y. Marumo, Screening of soil evidence by a combination of simple techniques: validity of particle size distribution, Forensic Sci. Int., 122, 155-158 (2001)

[9] B.D. Soane, The role of organic matter in soil compactibility: A review of some practical aspects, Soil and Tillage Res., 16 (1-2), 179-201 (1990)

[10] Y. Duraisamy, B.K. Huat, A.A. Aziz, Compressibility behavior of tropical peat reinforced with cement columns, American J. of App. Sci., 4 (10), 768-773 (2007).

[11] A. Zainorabidin, S.H. Mansor, Investigation on the shear strength characteristic at Malaysian peat, ARPN J. of Eng. and App. Sci., 11(3), 1600-1606 (2016)

[12] F.N.L. Ling, K.A. Kassim, A.T. Abdul Karim, Size distribution analysis of kaolin using laser diffraction technique, Adv. Materials Research, 341-342, 108-112 (2012) 
[13] M.I. Jaimi, Test Report of Sampel LMB03, Report No. BK 35/14, Forest Research Institute Malaysia (FRIM), Kepong, Selangor, (2014)

[14] BS1377-2, Methods of test for soils for civil engineering purposes. Classification tests, British Standards, London, (1990)

[15] A.S.A Rashid, K.A. Kassim, A. Katimo, M.N. Norhazilan, Determination of plastic limit of soil using Modified Methods, Malaysian J. of Civil Eng. 20(2), 295-305 (2008)

[16] BS1377-3, Methods of test for soils for civil engineering purposes. Classification tests, British Standards, London, (1990)

[17] F.N.L. Ling, Physico-chemical and microstructure of artificial soils stabilised with lime-zeolite, PhD Thesis, Universiti Teknologi Malaysia, Johore, (2016)

[18] F. Pakir, A.T. Abdul Karim, F.N.L. Ling, K.A. Kassim, Effect of humic acid on geochemistry properties of kaolin, Adv. Materials Research, 701, 310-313 (2013) 